\title{
Choice, diversity and 'false consciousness' in women's careers
}

\author{
Dr Val Caven \\ Dept of Human Resource Management \\ Nottingham Business School \\ Nottingham Trent University \\ Nottingham \\ NG1 4BU \\ England
}

Tel: + 44 (0) 1158484233

Fax: + 44 (0) 1158486512

E-mail: valerie.caven@ntu.ac.uk

\begin{abstract}
Dr. Val Caven is Senior Lecturer in HRM at Nottingham Business School. Her research interests include work orientations and professional employment particularly women in male-dominated professions. She has recently begun work on men’s work orientations and careers.
\end{abstract}




\title{
Choice, diversity and 'false consciousness' in women's careers
}

\begin{abstract}
The central theme of this paper is that contemporary literature concerning women's careers is based on assumptions held by researchers and not actually on views held by women themselves. Many feminist researchers are guilty of assuming 'false consciousness' on the part of their subjects by explaining these women as being victims of gender or patriarchal systems instead of making a mindful decision founded on choice. The empirical work draws on in-depth interviews with 39 women architects. Of the 39 women interviewed, 20 had adopted alternative ways of working, in the sense that they had rejected the conventional career within an organisation. Their reasons for this were diverse and ranged from wanting to combine childcare or elder care with work; involvement in local politics; wanting time for further study or sporting activities; as well just not wanting to work fulltime. In short, this research demonstrates that work is not always a central interest in the lives of individuals and supports Hakim's view of heterogeneity among women.
\end{abstract}

Key words: women's careers, non-standard work, preference theory

Word count: 7956 (including references)

\section{Introduction}

Conventional literature regarding women's careers assumes that women want to work full-time and alternative forms of work organisation other than an upward, linear progression within an organisation are regarded with a sense of failure (Mallon and Cohen, 2001). Hakim's (1996, 1998, 2001, 2002, 2003) contention that women have differing orientations to work challenged many of these assumptions and became the subject of much derision from her critics (Crompton and Le Feuvre, 1996; Crompton and Harris, 1998; Ginn et al, 1996; Bruegel, 1996; Walsh, 1999; Procter and Padfield, 1999; McRae 2003a, 2003b). The only area of common ground appears to be that McRae (2003a, 2003b) concurs that most sociological theory is inadequate at explaining women's employment decisions. 
Sociological theories over-emphasise structural factors and micro-level explanations such as preference are ignored (Hakim 2002). However, many women want to care for their own families (Meiksins and Whalley 1998) rather than relying on institutional care and do this by adopting work patterns which allow them to maximise both their employment careers and family life (Walsh 1999; Meiksins and Whalley 1998; Tilly 1996). Hakim’s critics have largely overlooked this fact preferring instead to focus on economic and social factors (McRae 2003a, 2003b) and lack of institutional childcare as the major constraints upon women's employment (Crompton and Harris 1998; Crompton and Le Feuvre 1996; Ginn et al 1996; Bruegel 1996). This ultimately means that children are seen as a barrier to a career whilst the reality is that many women want to pursue both a career and motherhood, expecting both to be equally rewarding (Meiksins and Whalley 1998; Procter and Padfield 1999; Walsh 1999). In addition, Hakim's critics focus only on the presence of children as influencing women's orientations to work when Hakim (2001) herself makes mention of women without children preferring to work reduced hours because they are involved with politics, voluntary work and the like.

The central theme of this paper is that contemporary literature concerning women's careers is based on assumptions held by researchers and not actually on views held by women themselves. Many feminist researchers, especially the critics of Hakim, are guilty of assuming 'false consciousness' on the part of their subjects by explaining these women as being victims of gender or patriarchal systems (see Millen 1997; Anderson 1981 cited by Reinharz 1992), instead of making a mindful decision founded on choice. The empirical work draws on in-depth interviews with 37 women architects who, to varying 
extents, represent Hakim's three typologies of work-centred, hone-centred and adaptive women but the main emphasis is on those women who have adapted their career to accommodate either their caring responsibilities or their involvement with other nonwork activities such as politics and voluntary work.

\section{Choice and diversity in women's careers: the current perspective:}

"Existing economic and sociological theory has a male bias in that it was developed primarily with reference to male labour market participation and the characteristics of men's work-life histories. Modifications and extensions were added later, in an attempt to cover the visibly different patterns of female employment. However, it is not satisfactory to explain women's employment as a small deviation from the employment patterns of men, or under the heading of sex discrimination, as so many textbooks do. Far better is a theory that starts from the substantial body of new research evidence on women's work, and that focuses on what is distinctive about the choices women make” (Hakim 2001:1-2).

The value of Hakim's contribution cannot be overlooked; she challenges dominant thought and argues that because women are different then different theories apply to them. Until now the prevailing view has been that the systems are "designed and administered by and for men - taking men's careers and attitudes as the norm and never questioning that this is in the interests of the organisation" (Rothwell 1982:19) nor questioning whether they are in the interests for women or society in general.

In mainstream career theory the belief is that the masculine career pattern is suitable for women if marriage and childbearing are taken in to account (Super 1984). Super's explanation for this is that because career choice is affected by self-concept which he hypothesised was the same in both men and women; they both make decisions based on self-concept and their image of the environment in which they live. However, it is argued 
that this fails to take into account the experiences of women and once again attempts to modify women into ‘quasi men’ (Gilligan 1979).

White males are now a minority in most Western labour markets due to the increase in working women and increased levels of ethnic minority representation (Baruch 2004) but these labour markets are still dominated by outdated working practices and a refusal to adapt. However, the balance of power is still in favour of white males with men holding the majority of managerial (and above) positions and enjoying a substantial pay differential in their favour (Baruch 2004).

It is not just from the masculine perspective that women and their work are attacked, women too perpetuate negative images with Coward (1992) accusing women of 'colluding' with men to maintain the gender imbalance; Crompton and Le Feuvre (1996) argue that women who work part-time are less committed than those who work full-time; and that older women have reduced expectations of career and work (Bruegal 1996).

The critics of Hakim's work focus on institutional and structural disadvantages experienced by women as explaining women's orientations towards their careers (Crompton and Le Feuvre 1996; Crompton and Harris 1998; Ginn et al 1996; Bruegel 1996; McRae 2003a, 2003b). Crompton and Harris (1998) suggest that women do make choices about their level of involvement in the labour market but that "women's employment behaviour is a reflection of the way in which women actively construct their work-life biographies in terms of their historically available opportunities and 
constraints” (Crompton and Harris 1998:119). Because historically women’s working lives have been constrained by structural and cultural barriers, Crompton and Harris (1998) argue that any 'choices' made by women will also be limited. Whilst this may be the case, it can then be said that all choices are made subject to constraints and restrictions and that no choice can ever be considered as freely made. In fact, as Hakim points out, women do enjoy a greater freedom of choice in their working lives than men, she says:

It is notable that there is in practice only one 'choice' of work history for men, compared to three for women. Feminists who emphasise that women's choices are constrained and not 'completely free' overlook the fact that women have more choices than men (Hakim 1996:134, emphasis in original).

A further point is that many women actually want to look after their own children and not rely upon institutional childcare (Meiksins and Whalley 1998). They do this by adopting work patterns which allow them to maximise both their employment careers and family life (Walsh 1999; Meiksins and Whalley 1998; Tilly 1996). Hakim’s critics have largely overlooked this fact preferring instead to focus on lack of institutional childcare as a major constraint upon women's employment (Crompton and Harris 1998; Crompton and Le Feuvre 1996; Ginn et al 1996; Bruegel 1996). This ultimately means that children are seen as a barrier to a career whilst the reality is that many women want to pursue both a career and motherhood, expecting both to be equally rewarding (Meiksins and Whalley 1998; Procter and Padfield 1999; Walsh 1999).

Furthermore, there is the question of why so many women who do not have dependent children continue to work part-time? Walsh (1999) found that there are a significant 
number (over a quarter of her sample) who did not want to work other than part-time and had no dependent children, she says:

They had chosen such arrangements for social contact, financial reasons, or because they had no interest in full-time work. There was no evidence of an unfulfilled or latent demand for full-time work amongst these women. Indeed, over three quarters (79 per cent) indicated that they did not wish to return to fulltime work in the future (Walsh 1999:190).

It is these women that who are of particular interest and who represent the challenge for HRD in terms of job design and career structures. Hakim's (2001) explanations, while valuable, are too simplistic as she links reduced involvement in the labour market purely to women's homemaker role and ignores other explanations.

\section{Human capital theory}

A further dimension is thus added, once there is a distinction made between primary and secondary earners, there must also be a differentiation concerning firstly the motivation to seek, and secondly to remain in, employment. Primary earners do not have the extent of choice regarding whether to seek or remain in employment that secondary earners possess. Secondary earners may choose between domestic and market work. This is seen as 'rational' decision making within 'new home economics', it refers to where a woman (usually) takes responsibility for the domestic work, thus sacrificing investment in human capital (Becker 1981). This, Becker argues, makes economic sense because starting from the assumption that both husband and wife are in all ways equal, it improves economic efficiency if one specialises in paid employment while the other assumes responsibility for the domestic

work. This has been interpreted as reinforcing occupational segregation to prevent women 
from playing an equal part in the work place because wives who do work will seek less demanding jobs (Crompton and Sanderson 1990; Hakim 1996).

\section{Production versus Reproduction: Feminist Theory}

Feminist explanations, in particular Marxist, Socialist and radical forms, dominate sociological studies; however there is much diversity and a lack of consensus within different forms of feminism. While there are problems with women being considered along side the masculine model many studies of women are biased too because of the explanations imposed on them.

A major element of both Marxist and radical feminism is the 'social' versus the 'biological' account of sexual inequality. Since Wollstonecraft (1759-97), the early feminists had believed that the subordinate position of women was socially constructed and not, as was commonly believed the result of the dominant religious teaching. Class divisions, rather than gender, are considered to be the cause of women's oppression. The family unit also causes problems for Marxist feminism as capitalist societies rely on women's biological ability to create future workers and this contributes to women's inferior economic and social status.

Radical feminism takes patriarchy as its explanation of female subordination. This is the domination of women through male violence and suppression with the result that social structures have emerged to maintain this. There is no advantage to men in changing this situation, society is dominated by men and masculinity, and historically women's roles have existed in order to 'service' men. Women possess greater 'value' to men and masculine 
society, by remaining in these roles. Insurance companies estimate that the cost of replacing the domestic services provided by a housewife is over $£ 20,000$ per year. The solution to this, according to radical feminists, is the separation of men and women and the creation of separate structures away from those created by men, which amounts to a fundamental refocusing which attempts to reflect women's lives in a feminist context.

Liberal feminism takes a less polemic perspective but covers a far wider range of perspectives. It does not attempt to apportion the subordination and exploitation of women to one single factor but instead tries to explain the situation in terms of events and circumstances which prevent women from taking advantage of the opportunities available to them. Examples of these are that discriminatory practices within organisations are the root cause of horizontal segregation and that the organisation of society 'encourages' women into making certain 'choices' about their careers. Legislation has been introduced in an attempt to create greater gender equality, with the intention that if attitudes can be gradually changed and discriminatory practices prevented then equality will result. However, liberal feminism does not explain how women's position within society became established as such in the first instance and is criticised for failing to deal with deeper issues of subordination.

These approaches to feminism have the universal theme of requiring unitarist, collective action in order to challenge women's oppression and this contributes to why they can be problematic concepts (Gamble 2001). Common to these strands of feminism is the issue of consciousness-raising whereby "the move to transform what is experienced as personal into analysis in political terms, with the accompanying recognition that 'the personal is political', 
that male power is exercised and reinforced through 'personal' institutions such as marriage, child-rearing and sexual practices” (Thornham 2001:30). Heywood and Drake (1997 cited in Thornham 2001) recognise this lack of plurality as causing a problem for feminism in that one of the major problems faced by feminism is that it assumes a female consensus on relationships with men, employment and belief systems.

However, Greed's (1991) notion of 'bourgeois feminism' approaches the debate in an entirely different manner. This she defines as a non-radical feminist or in simple terms, a business woman. Greed argues that this type of feminism arose during the 1980s as a result of "wider political changes" (Greed 1991:10) and that it is more appropriate for women employed in the more conservative professions. She explains that bourgeois feminists:

... seem quite alienated from feminism and may never have read any feminist literature. Yet they possess some measure of feminist consciousness of their own, but are unlikely to express themselves in feminist jargon. They may not identify 'patriarchy' as the cause of their problems, or even think in terms of macrosociological first causes (but undoubtedly experience their effects). They are more likely to see their problems as being personal, and either their own fault or that of those who work with them. They may be put off by the false media image of feminism and 'the way feminists dress and carry on'. (Greed 1991:11).

Where this form of feminism radically differs from its more politically motivated counterparts is that it does not lay the blame solely on men or society. Instead it internalises the difficulties that women face but it nevertheless reflects how some women feel. As Greed highlights, such professions as architecture and surveying are traditional and conservative with the result that they are unlikely to attract recruits of a more radical or nonconformist nature. However, in the sense that bourgeois feminists are business women (Greed 1991), they can be said to have more of a sense of feminist individuality than collectivity. 
Feminism of all diversity provides difficulties for those women who are 'home-centred' as these women are supposedly guilty of colluding with men and masculine structures (Coward, 1992). The role of mothers is devalued and motherhood becomes an objective state. The first national British Women's Liberation conference was held in 1970 and one of the demands was for 24 hour nurseries thus removing any form of maternal (or even paternal) attachment to children. Walsh's (1999) study showed that 58\% of women chose part-time work because of childcare; Meiksins and Whally (1998) contend that women actually want to be with their children; and, Coward (1999:163) cites the need for "that feeling of centrality to their children's lives” as being important to women.

Coward (1999:65) argues that "feminists are refusing to look at data on the economy and gender division, and especially what ordinary people might be feeling about this, in any light which would undermine fundamental beliefs about the multiple disadvantages of women”. Here she is introducing the notion, which provides the focus of this paper, of what matters to 'ordinary people' and acknowledges the fact that feminists are still concentrating on women being disadvantaged by male power. While she is a little critical of Hakim's preference theory on the grounds of its simplicity she does contend that "sometimes decisions are to do with quality of life: either women are privileged enough to have a choice, or they value time with children above the strains of full-time employment even if it means economic hardship" (Coward 1999:67).

\section{False consciousness and the challenges for HRD}


Greed's description of bourgeois feminism does not chime with the opinions of academics who impose their explanations upon women's position in the workplace arguing that it is structural and institutional factors which prevent women from competing with men on truly equal terms. Hakim's (1998, 2001, 2002, 2003) work on preference is valuable in that it acknowledges the choices that women make although she does restrict her explanation to the presence or absence of children and does not include those who are either childless or who no longer have dependent children.

The challenge for HRD is twofold: firstly, to recognise that many of the explanations for women's positions in the labour market are as a result of academic researchers assuming 'false consciousness' on the part of their subjects by explaining these women as being victims of gender or patriarchal systems (see Millen 1997; Anderson 1981 cited by Reinharz 1992), instead of making a mindful decision founded on choice. The totalitarian way in which these 'rationalisations' are imposed upon women runs counter to the emancipation of women and merely inflicts another form of oppression.

There are no specific sets of techniques that can be labelled a feminist methodology but all forms of analysis are acceptable 'for investigating the condition of women in sexist society' (Stanley 1990). It appears that the role of feminism is more a way of seeing, a way of knowing and a way of being in the world (Stanley 1990). It exists in a conceptual sense but manifested itself within the research process. Whilst there are no prescribed techniques which comprise a feminist methodology, there are certain criteria which include the experiences of real people as used as the basis for generating knowledge and 
that there is an aim for change in some way. These are supported by the use of nonabusive research methods within which there is reflexivity between the researcher and research.

Bryman and Bell (2003) discuss the dilemma of when researchers do not believe what their subjects tell them and thus seek to impose their own explanations. In the case of Anderson's research, she interpreted responses as 'false consciousness' but after her findings were published, she received a letter from her interviewees challenging her interpretations (Anderson 1981 cited in Reinharz 1992). Millen, too, experienced similar difficulty where she says she was aware of sexism affecting the subjects of her research but that "the women ... did not generally view their interactions in terms of gendered social systems. There is therefore a tension between their characteristics of their experience and my interpretation of it” (Millen 1997:5.6, 5.9). Greed (1991) says many women in professional employment have not read any feminist literature and, as a result, have not developed a raised consciousness. However, this is passing the 'blame' onto women and points to where the source of the conflict lies, as Bryman and Bell (2003) argue, any explanation or interpretation that is conferred on women that is not shared by them raises moral and ethical questions.

Secondly, it is apparent that women do want to play an integral part with their families or non-work activities and this should not be viewed as a weakness or as rejecting their career. If, as Hakim states "virtually all part-time work is voluntary, in the sense of being preferred over a full-time job” (1996:71) then are those people who work reduced (but 
regular) hours more content and will they display a higher level of commitment to their employer as suggested by Walsh and Deery (1999)? As McGoldrick et al (2002:396) state "HRD will become increasingly concerned with facilitating the learning of individuals, teams and organisations through the design, structuring and organisation of work itself" which in itself implies the need for increased acceptance of diversity in work. The research issues of this study are to explore whether feminist explanations of women's involvement in the labour market accurately reflect the intentions of the women themselves.

\section{Methods}

The research focuses on the careers of 37 women architects located in the East Midlands region of the United Kingdom. The area comprises a mixture of urban and rural locations and there are almost 200 architectural practices (RIBA 2004) which are a combination of regional branches of large national organizations coupled with local firms of varying size. The mix is representative of architectural practices located outside of the Greater London area (RIBA 2004). The proportion of women architects is significantly lower than the national average of $14 \%$ (RIBA 2004) with only 49 women RIBA members out of almost 1000 architects employed in the region.

All 49 female RIBA members were contacted by post and, of these, 37 agreed to be interviewed. Their ages ranged from 27 to 72 and included two women who were retired but who still retained their membership of the RIBA, a further one was on a career break and another was unemployed. They were included because their experiences were 
considered to be valuable as they represented those who retained a connection with the profession although not working in it at the time. The two older women were able to give a useful perspective on the changes which had taken place over their working lives. Their areas of employment and numbers of dependent children are shown in Table 1 below:

\section{Insert table 1}

The table shows that of the 37, only 11 are full-time salaried working in an architectural practice or company; one is full-time salaried as a lecturer in higher education and another is full-time salaried but working for a development corporation; 2 are part-time salaried. Neither of these two have dependent children: one teaches part-time in a local school of architecture and the other is a semi-professional sportswoman who needs to spend time training. Two are employed on short term labour-only contracts and the remaining 17 (excluding those who are retired or on a career break) are either principals of practices or sole practitioners. This is significantly more than the national average of $48 \%$ of architects who are principals or sole practitioners. Overall, those who have adopted a non-standard way of working represent 20 of the 37. Non-standard forms of work are usually taken to mean part-time and temporary work and self-employment although it has come to encompass any work which is neither full-time nor permanent with a formal contract of employment for an indefinite period, such as subcontracting, flexi-time, fixed term contracts and the like (Yeandle 1999; Felstead and Jewson 1999). 
In-depth biographical interviews using a career life history approach were carried out with the interviewees. The discussion was based around seven subject areas relating to why they chose architecture as a career, factors which have helped and hindered their careers, the pressures and satisfactions of an architectural career, life outside work, the effects of being a woman in a masculine environment and future career plans. The subject areas were not designed to be specifically question and answer type topics but areas for discussion where areas of interest could be probed further. The interviews lasted from between 40 minutes (the interviewee's time was limited) to over 3 hours. Each interview was taped and transcribed, NUD.IST qualitative research software was used to help with the coding and ordering of the themes and issues which arose from within the data.

\section{Choice and Diversity in women's careers: a new perspective?}

There are two main themes to be explored here: firstly, there is the attraction of nonstandard working as adopted by the women which amounts from wanting to do things other than work full-time and the discussion here covers there being more to life than work and wanting to provide childcare; secondly, there is their rejection of feminism. Non-standard working is adopted by 20 of the women interviewed, most of whom were childless or had no dependent children. There is an implicit assumption that selfemployment, in the form of sole practitioner, principal in practice or on a labour-only basis, exists primarily as a solution to the problems of juggling family and career (Goffee and Scase 1985; Hakim 1995, 1996; Crompton and Le Feuvre 1996). However, meeting family responsibilities was not the only reason for becoming a sole practitioner as four of the nine sole practitioners were childless and the other two formed their practices after their children were grown up. Their reasons for becoming self-employed are varied and 
include needing to be able to work part-time and flexibly because of ill health. However, the majority of sole practitioners are childless or no longer have dependent children which means then, that this form of working arrangement is not entirely due to needing to combine work and childcare. Other factors must come into play in order to attempt to explain the rationale for this type of working arrangement and these will now be discussed in the following sections. Firstly, issues relating to non-work activities will be considered; this will be followed by an investigation into the integration of childcare and career; thirdly, we will discuss the meaning (or lack of) that feminist theory has for these women.

\section{There's more to life than work:}

This theme was reflected strongly by many of the interviewees, of the four quotes below only one (Karen) has dependent children. Rachel's children are in their late teens so are financially dependent but are not in need of childcare. Barbara and Cindy are childless.

I always feel it's a silly way to organise your life to have to work so hard and not do anything else (Rachel)

I'd rather dig my allotment than take jobs that I don't want to do. The career is important but not the most important part of my life, quality of life is important to me. You don't have to earn all this money, have a life! (Barbara)

I've got involved with the local access group, through the children, through the NCT, which I got involved with, representing mothers with children in buggies ... and then recently [became] the Chairman, I got involved in East Midlands Training Partnership, which is a training agency and I'm a director there. I've also been involved with the Play Forum, and got involved with the design course that they ran (Karen)

I'd expressed an interest when I finished university that it would be quite nice to come back if they ever needed any tutors or anything and the Prof actually rang up and said 'We do need someone for the first year, would you be interested?' so 
it's just part-time and it works really well. It's good to do something different apart from go to work (Cindy)

While Karen's other roles could be considered to be work-related, her involvement is in an unpaid capacity and her interest arose as a result of having children. Sylvia is a semiprofessional sportswoman and works part-time in order to be able to train; Melanie has an allotment and is involved with a local ecology group campaigning on green issues, however, she also has health problems and is unable to work full-time; Olivia is a charity fundraiser; Barbara also has an allotment and is a local councillor; Phyllis is taking a garden design course; and Rosie is a school governor and helps out regularly in class listening to children read. These women have chosen unpaid activities in addition to their paid work for implicit rewards only. Melanie and Sylvia are both single (and childless) and have made life-style choices while still having to be self-supporting without a partner's salary to help.

Others have additional businesses - Rachel and Ursula both invested in property which provides them with an income; Sheelagh owns two day nurseries and is actively involved in the day to day running of them. Angela's teaching work is paid but it means she has part-time status for both the Local Authority and the School of Architecture. All these women are single and self-supporting but are looking for alternatives to the full-time career.

We do this development work ... we had some spare capital that we invested a long time ago but we paid very little for it and it's never owed us anything and over the years we've sold them off or whatever. We sold one off and bought some property in [ $\mathrm{N}_{\text {___ }}$. We have the income from the lease and that's been fun doing that, it's been nice not to have a client and to do something you want to do and it would be fun to do more of that but that depends on all sorts of things. If you've 
got to do it for a living it's slightly different than taking the opportunity when it arises. (Rachel)

I'm not ambitious, I'm there to enjoy meself, ... I mean I've been offered some wonderful jobs and I don't want the aggravation ... quite honestly I don't want the hassle. I bought a lot of property I did sort of mortgage myself rather high but as an investment and I've got to the stage now where ... that if I don't work then it doesn't matter. I've got properties rented out that bring in an income so I'm at that stage where I think I’m all right. (Ursula)

Even without the financial cushion of additional forms of income, there is a desire to make choices over working time:

if I can get in the car and it's two minutes down the road I'm more interested ... by and large, I can say 'no I don't want to do that' I don’t struggle to get work by any means. [My career has] been better since I became self-employed ... basically nobody can bug you .... You are in control of your own career and I find it much more pleasant (Christine)

\section{Childcare:}

For the older women, it seems there was never any question of whether or not they would look after their own children but they negotiated forms of working that suited their individual needs. Evelyn, one of the oldest interviewees, married soon after qualifying and had six children but continued to work on a part-time basis.

I was lucky to find one [part-time job] which really suited me. I could do as many hours as I liked or as many hours as they wanted. I don't think it was so easy in those days to get part time jobs. I found definitely if you were doing say three days a week you couldn't do working drawings because you couldn't get it finished quick enough so that's why I only did planning drawings and things like that which only required two or three drawings and you get them done in reasonable time. So it limited what you could do. I didn't mind that because I wasn't ambitious (Evelyn) 
The notion of part-time work within a profession at this time was, in a theoretical sense, non-existent but was operated here in more of an informal context. Two others (Amy and Olivia) also worked part-time at some stage in their careers, one during the 1970s and the other during the 1980s displaying an ' $\mathrm{M}$ ' shaped career pattern by moving back to fulltime employment once their children were older (Dex 1987). This illustrates the use of part-time employment as a means of combining work and family either by it providing the best solution (Tilly 1996) or because family responsibilities prevent full-time working (Peitchinis 1989).

I've given my all [to my career] and I've given my all to the children as well (Olivia)

Among the younger women there was a conviction that they wanted to be involved with their children during their childhood:

I mean I don't believe in farming kids out when they're young, I mean I think people have to do it I appreciate that but I don't think I could (Ursula)

I really wanted to be at home with the children, I really wanted to be there for them, while I found it difficult, I mean I did need the stimulus of a job ... so it just seemed right that if people asked me to do a job, I could do it around the children so it just gradually built up (Rosie)

I think it's more important to be at home with your children. I'm a member of Full Time Mothers, which advocates that people should have a right to stay at home and look after their own children, because I don't think it's good for kids to be child minded all the time (Susan)

For me it's worked quite well because having started my own practice, which I did when my child was about a year old, I have been able to work it in with having a child as well. (Sheelagh) 


\section{A feminist approach?}

The women were asked why they chose architecture as a career knowing that the construction industry is perceived as a masculine domain and not regarded as an appropriate field of employment for women (Greed, 2000; Agapiou, 2002; Fielden et al, 2000; Ellison, L. 2001). The commitment required prior to qualification in terms of time spent studying would suggest that the choice of architecture as a career would be made following a thorough examination of individual self-concept and the environment in which that individual lives (Super 1984) or by the 'matching' of the individual and occupation (Hall 1976). It would suggest that a certain amount of research would be carried out and careers advice sought. However, the reality indicated that career choice was resolved along more subjective lines (Evetts 1996) determined to a large extent by social factors (Banks et al 1992).

The most common response to being asked why architecture was chosen was that it was a 'basic instinct' developing in childhood. Certainly, childhood and family background plays an important part in career choice (Banks et al 1992). Firstly, there is the 'it was just something I always wanted to do' type of explanation where an interest in architecture develops in early childhood without, it seems, any specific reason for making this choice. Secondly, there is also evidence of both parents' interests and parents' professions playing a significant role in influencing career choice with several of the interviewees stating their parents had been employed in the construction industry in some way. 
It is reasonable to expect that these women would be aware of the masculinity surrounding the industry and to perhaps enter the architecture profession as a feminist in order to challenge the status quo. However, when they did comment, it was usually along the lines of that reported by Greed (1991) by stating that they were not feminists in any way:

I'm not an architect because I'm trying to prove women can do it, I'm not remotely feminist or anything like that. I do it because I thought it would be the most interesting career when it came to choosing careers (Cindy)

This is supported by Isabel who feels it would have a negative impact on her if she were to be seen as a feminist:

I'm not one for burning your bra anyway, I'm not that sort but quite honestly I think if you had that sort of attitude it would get up their noses anyway. I always thought it would go against me I don't consider myself to be a career woman, it's just something I enjoy doing and that's it, as far as it goes. (Ursula)

Paula once worked for a women-only architectural co-operative but has reacted against the ethos since leaving:

... I do try very hard not analyse everything in terms of feminist analysis ... the women at [the co-operative], just because that organisation was set up very specifically about women in architecture, you couldn't help but address the problems all the time. They were coming to you with the issue all the time, they were expecting you to have a view. (Paula)

The architecture co-operative has a very strong feminist agenda as well as the objective of challenging the 'man-made' environment (Matrix 1984) and she found the constant emphasis on feminist issues somewhat demanding. It is apparent that there is a distinct lack of feminist solidarity or unitarism among these women. Only Alex is prepared to 
further the interests of women generally within the profession. She has greater potential to do this than any of the others as she is course leader at a School of Architecture but even then she qualifies her statement by playing down feminism:

My colleagues have got used to me reminding them, that when we think of a name we should be thinking of a woman not [just] a man and I mean, it's taken me five years but they do now know me well enough to accept what I'm saying and to know that actually I'm not you know a strident sort of bouncing feminist. I just feel very strongly that you know we've got to give people equal chances (Alex)

Here Alex regards herself as promoting Equal Opportunities in the School of Architecture where she works rather than taking an overtly feminist stance. She says she is not a 'bouncing feminist' but that she believes in equality. Many of the interviewees were keen to stress their rejection of feminism but highlight the role of women:

I'm not a women's libber but ... I think we're more proactive. I notice that with one of my colleagues here who is the support services manager and if you want anything done anywhere in this division you ask her and that happens to me a bit as well. ... I'm not too worried about apportioning roles ...I don't think women have got egos the same as men have which can get bruised and damaged. (Pat)

Greed (1991) says that many professional women have not had their consciousness raised regarding feminism, once again apportioning 'blame' on to women. These women seem well aware of feminist principles but are choosing to avoid being involved themselves. They are not denying the role that feminism has played in gaining equal opportunities but the way their working lives have evolved going against feminist hypotheses regarding their careers indicates how much theory relating to women's careers is not as relevant as much literature would have us believe. 


\section{Conclusions}

This paper has reported the stories of the women who took part in this research study. It has given them their own voice and presented their interpretations of their accounts rather than having explanations provided on their behalf. These women are working in a maledominated profession and industry; they have chosen architecture as a career and have undergone a lengthy process of training prior to qualification. In addition, these women have forged a career as architects in contrast to recent research in architecture which focuses on those who have left the profession (de Graft-Johnson, et al 2003; Adams and Tancred, 2000). The women are exercising choice and introducing diversity into working practices. The high levels of non-standard working may be a response to organisational reluctance to providing flexibility and diversity in work but contrary to mainstream literature on women's work, where alternative forms of work organisation other than an upward, linear progression within an organisation are regarded with a sense of failure (Mallon and Cohen, 2001), these women report that they are content and, to them, it represents career success because they are able to balance work and non-work activities.

The point is not to deny that women are not discriminated against or to give the impression of an overly rosy perspective of women's careers but to open the debate to other streams of thought than those which are currently under discussion. Existing rationalisations of women's career patterns tend towards being overly pessimistic and patronising due to feminist reliance on explanations relating to the masculine model of

employment. Feminist activity has played a valuable part in shaping women's current position in society, in achieving autonomy and equality however "the old feminist 
equation that being a woman necessarily entails low income and low status is no longer always true" (Coward 1999:50). These women have shown how they have combined work and non-work activities in order to maximise other opportunities or for quality of life. They are not rejecting their work or careers per se but they show that work is not necessarily as great a central life interest as suggested by feminist literature.

The extent to which the women are adapting their lives to accommodate elements away from the full-time career and their antipathy towards feminist explanations suggests that there is more diversity than existing research suggests. These women do not present themselves as victims of patriarchal systems; they have made choices within the limits of their own lives and experiences. To this end, they are effectively rejecting feminist suggestions that they are somehow considered second best to men. The test for HRD is to be able to recognise and incorporate this diversity into developing theory based on reflexive practice. 


\section{References}

Adams, A. and Tancred, P. (2000) Designing Women: Gender and the Architectural Profession. Toronto, University of Toronto Press.

Agapiou, A. (2002) Perceptions of gender roles and attitudes toward work among male and female operatives in the Scottish construction industry. Construction Management and Economics, 20, 697-705.

Banks M., Bates I., Breakwell G., Bynner J., Emler N., Jamieson L. and Roberts K. (1992) Careers and Identities. Milton Keynes, Open University Press.

Baruch, Y. (2004) Managing Careers: Theory and Practice. Harlow, FT Prentice Hall.

Becker G.S. (1981) A Treatise on the Family. Cambridge, Mass., Harvard University Press.

Bruegel, I (1996) 'Whose myths are they anyway?: a comment.' British Journal of Sociology 47, 1, March, 175-177.

Bryman, A. and Bell, E (2003) Business Research Methods. Oxford, Oxford University Press.

Coward, R. (1993) Our Treacherous Hearts. London, Faber and Faber.

Coward, R. (1999) Sacred Cows. London, HarperCollins.

Crompton R. and Sanderson K. (1990) Gendered Jobs and Social Change. London, Unwin Hyman.

Crompton, R. and Le Feuvre, N. (1996) Paid Employment and the Changing System of Gender Relations: a Cross-National Comparison. Sociology. 30, 3.

Crompton R. and Harris, F. (1998) Explaining Women's Employment Patterns: 'Orientations to Work Revisited'. British Journal of Sociology, 49, 1.

De Graft-Johnson, A., Manley, S. and Greed, C. (2003) 'Why do women leave architecture?’. RIBA/University of West of England Research Project. London, RIBA.

Dex S. (1987) Women's Occupational Mobility: A Lifetime Perspective. London, Macmillan.

Ellison, L. (2001) Senior management in chartered surveying: where are the women? Women in Management Review, 16(6), 264-78.

Evetts J. (1996) Gender and Career in Science and Engineering. London, Taylor and Francis. 
Felstead, A. and Jewson, N. (1999) Flexible Labour and Non-Standard Employment: An Agenda of Issues in Felstead A. and Jewson N. (eds) Global Trends in Flexible Labour.. London, Routledge.

Fielden, S.L., Davidson, M.J., Gale, A.W. and Davey, C.L. (2000) Women in construction: the untapped resource. Construction Management and Economics, 18 113-21.

Hall D.T. (1976) Careers in Organisations. Santa Monica, California, Goodyear.

Gamble, S. (2001) (ed) Feminism and postfeminism. London, Routledge.

Gilligan C. (1979) ‘Woman’s Place in a Man’s Life Cycle.’ Harvard Educational Review, 49, pp 431-446.

Ginn, J. Arber, S. Brannen, J. Dale, A. Dex, S. Elias, P. Moss, P. Pahl, J. Roberts, C. and Rubery, J. (1996) 'Feminist Fallacies: a reply to Hakim on women's employment.' British Journal of Sociology 47, 1, 167-174.

Goffee R. and Scase R. (1985) Women in Charge: The Experiences of Women Entrepreneurs. London, George Allen and Unwin.

Greed C. (1991) Surveying Sisters: Women in a Traditional Male Profession. London, Routledge.

Hakim, C. (1995) 'Five Feminist Myths about Women's Employment.' British Journal of Sociology, 46, 3, 429-455.

Hakim, C. (1996) Key Issues in Women's Work: Female Heterogeneity and the Polarisation of Women's Employment. London, The Athlone Press.

Hakim, C. (1998) 'Developing a Sociology for the Twenty-First Century: Preference Theory’. British Journal of Sociology. 49, 1,137-143.

Hakim, C. (2000) Work-Lifestyle Choices in the $21^{\text {st }}$ Century. Oxford, Oxford University Press.

Hakim, C. (2002) 'Lifestyle preferences as determinants of women’s differentiated labour market careers’ Work and Occupations, 29:428-59.

Hakim, C. (2003) 'Public morality versus personal choice: the failure of social attitude surveys’. British Journal of Sociology, 54(3), 339-345.

Mallon, M. and Cohen, L. (2001) 'Time for a Change? Women’s Accounts of the Move from Organisational Careers to Self-Employment’ British Journal of Management, 12, 217230. 
Matrix (1984) Making Space: Women and the Man-Made Environment. London, Pluto.

McGoldrick J., Stewart J. and Watson S. (2002) Understanding Human Resource Development: a Research-Based Approach. London, Routledge.

McRae, S. (2003a) 'Constraints and choices in mothers' employment careers: a consideration of Hakim's Preference Theory', British Journal of Sociology, 54(3): 317338.

McRae, S. (2003b) 'Choice and constraint in mothers' employment careers: McRae replies to Hakim’. British Journal of Sociology, 54(4): 585-592

Meiksins P. and Whalley P. (1998) 'Having It All? Orientations to Work and Family Among Part-time Technical Professionals'. Paper presented at Gender, Work and Organisation Conference, Manchester.

Millen D. (1997) 'Some methodological and Epistemological Issues Raised by Doing Feminist Research on Non-Feminist Women', Sociological Research Online, 2, www.socresonline.co.uk/2/3/3

Peitchinis S.G. (1989) Women at Work: Discrimination and Responses. Toronto, McClelland and Stewart.

Procter, I. and Padfield, M. (1999) 'Work Orientations and Women’s Work: A Critique of Hakim's Theory of the Heterogeneity of Women'. Gender, Work and Organization, 6, 3, $152-162$.

Reinharz S. (1992) Feminist Methods in Social Research. New York, Oxford University Press.

Rothwell, S. (1982) Women's Career Development: An Overview of the Issues for Individuals and Organisations in Cooper C.L. (ed) Practical Issues to Women's Career Development. Sheffield, Manpower Services Commission.

Royal Institute of British Architects (2004) Survey of Employment and Earnings. London, RIBA.

Stanley L. (1990) Feminism and the Academic Mode in Stanley L. (ed) Research, Theory and Epistemology in Feminist Sociology. London, Routledge.

Super D.E. (1984) Career and life development in Brown D., Brooks L. And Associates (eds) Career Choice and Development. San Francisco, Jossey Bass.

Thornham, S. (2001) Second wave feminism in Gamble, S. (ed) Feminism and postfeminism. London, Routledge. 
Tilly C. (1996) Half a Job: Bad and Good Part-Time Jobs in a Changing Labour Market. Philadelphia, Temple University Press.

Walsh, J. (1999) 'Myths and Countermyths: An Analysis of Part-Time Female Employees and Their Orientations to Work and Working Hours'. Work, Employment and Society June, 13, 2, 179-203.

Yeandle S. (1999) Gender Contracts, Welfare Systems and Non-Standard Working: Diversity and Change in Denmark, France, Germany, Italy and the UK in Felstead A. and Jewson N. (eds) Global Trends in Flexible Labour. London, Macmillan. 


\begin{tabular}{|c|c|c|c|}
\hline Name & Age & Children & Occupational status \\
\hline Sue & 27 & Childless & Director of company \\
\hline Jo & 30 & Childless & Salaried full-time \\
\hline Katie & 30 & 1 preschool & Salaried full-time \\
\hline Sophie & 30 & Pregnant & Full-time salaried \\
\hline Susanne & 30 & 1 preschool & Salaried full-time \\
\hline Zena & 30 & Childless & Salaried full-time \\
\hline Cindy & 31 & Childless & Salaried part-time/teaching \\
\hline Sylvia & 32 & Childless & Salaried part-time \\
\hline Ursula & 32 & Childless & Practice principal \\
\hline Marlene & 32 & Childless & Salaried full-time \\
\hline Geraldine & 33 & 1 preschool & Sole practitioner \\
\hline Julia & 35 & 2 preschool & Salaried full-time \\
\hline Kate & 35 & Childless & Labour-only contracts \\
\hline Rima & 35 & $\begin{array}{l}1 \text { preschool, } 1 \text { primary } \\
\text { school }\end{array}$ & Salaried full-time \\
\hline Melanie & 36 & Childless & Sole practitioner part-time \\
\hline Christine & 40 & Childless & Sole practitioner \\
\hline Lesley & 41 & 1 teenage & Salaried full-time \\
\hline Hannah & 42 & Childless & Practice principal \\
\hline Paula & 42 & Childless & Practice principal \\
\hline Susan & 42 & 2 primary school age & Career break \\
\hline Barbara & 44 & Childless & Teaching/drafting/sole practitioner \\
\hline Karen & 44 & 3 primary school age & $\begin{array}{l}\text { Salaried full-time development } \\
\text { corporation }\end{array}$ \\
\hline Rosie & 45 & 3 secondary school age & Sole practitioner part-time \\
\hline Sheelagh & 45 & 1 primary school age & Sole practitioner part-time \\
\hline Sheila & 45 & 1 primary school age & Practice principal \\
\hline Rachel & 45 & 2 teenage & Practice principal \\
\hline Constantina & 46 & 1 adult son & Sole practitioner \\
\hline Jackie & 48 & 2 adult & Sole practitioner full-time \\
\hline Joanne & 48 & 2 adult & Salaried full-time \\
\hline Liz & 49 & $\begin{array}{l}\text { 4: } 2 \text { at school, } 2 \text { at } \\
\text { university }\end{array}$ & Practice principal \\
\hline Alex & 51 & 2 teenage & University lecturer \\
\hline Pat & 53 & 2 adult & Labour-only contracts \\
\hline Olivia & 54 & 2 adult & Salaried in practice \\
\hline Amy & 55 & 4 adult & Unemployed \\
\hline Phyllis & 59 & Childless & Sole practitioner; garden designer \\
\hline Evelyn & 68 & 6 adult children & Retired \\
\hline Ella & 72 & 5 adult children & Retired \\
\hline
\end{tabular}

Table 1: Occupational status, age and number of children 
